interested in the Working Men's College in Brighton. What are we going to do? Tell them to take sociology courses? Or do historical research which might provide answers to this particular political struggle, the struggle of sexual politics that happened far, far away from the chancelleries and union halls that interest you? New groups of politically active people are now asking questions about different kinds of power relationships and are, therefore, researching such apparently "non-political" subjects as women's sexual experience or their physical experience with their bodies. We refuse to see this kind of "trivia" pushed aside by the fleshy body of British Socialism.

University of Toronto

\title{
Telling a Story in Context; or, What's Wrong With Social History?
}

Francis G. Couvares

One wishes the disputes under discussion here ${ }^{1}$ might be resolved by "the construction of a historical science" which puts "the fundamental problem of power and order ... at the center of the historical process," allowing plenty of room for Class Struggle at the barricades, no less for long-term changes in mentalities and repertoires of resources, for formal politics, and even a little for menarche. It seems unlikely, however. And for my part it is, one small wishful moment aside, largely undesirable. For, like most historians, I find the snares of nominalism and "ye olde empiric shoppe" less fearful than those of the Big Agenda. Whether this is the result of theoretical backwardness or political cowardice (these do seem to be the alternatives) I leave to others to decide. What follows, however, is a somewhat scatter-shot commentary on some of the arguments advanced by Judt, Shorter, Stedman Jones, the Genoveses, and the Tillys. Both the methodological and ideological agendas advanced for social history lose their persuasiveness when they depart from the desire of most historians to perform their central task: to tell a story in context. That the historian's story is based on documentary evidence distinguishes its principal means of explanation not at all from other literary forms of storytelling. That means is descriptive narrative. Narrative is not merely the icing on the cake; whose batter might be thought of as the analytic content; it is not merely a more or less facile presentation of the results of research. While it allows plenty of space for "synchronic" contextualizing, narrative itself bears most of the burden of explanation, of connecting events in a plausible sequence. ${ }^{2}$

Against Louise Tilly I would assert that narrative is neither simple nor necessarily about politics. One may narrate the life of the mind, the progress of poverty or the decline of artisanal culture. At times the need to recontextualize may be so great that long interruptions in narration are needed to allow detailed, perhaps quantitative analyses of conditions and contexts. Perhaps this pause must at times extend to whole books, whole careers, whole schools. But I doubt it can be put off for long without stimulating in historians a powerful appetite for biography, histoire événémentielle, and whatever species 
of heroic tale Judt and his colleagues will be turning out. Moreover, it is a mistake to underestimate the variety and flexibilty of narrative. The nineteenth-century omniscient narrator no longer holds sway over the novel, if he ever did. Consider the spectacular diversity of narrative forms conjured up by Dickens, Zola, Conrad, Joyce, Faulkner, and Mailer. Gene Wise has suggested that historians can derive a sophisticated, multi-perspectival form of narration from Faulkner. ${ }^{3}$ And historians are only now beginning to learn from movies and photojournalism new ways to present several voices or levels of narration while sustaining a coherent point of view. 4

The appeal of the new social history is its ability to correct our stories in two ways. First, in response to the history-from-below impulse, it adds new stories or new voices and characters to old stories. Second, it deepens and broadens the contexts of our stories. Since the meaning of the story changes with the context, new interpretations of key historical phenomena have become available. What is wrong with the new social history is its dependence upon a base-superstructure theory of culture. Its practitioners mistake contexts for causes. ${ }^{5}$ When they bother to narrate, their stories end up sounding like epilogues to the main action (which has gone on in the British Museum or the Computing Center). Many social historians escape this fate. Eugene Genovese, for example, has never failed to confuse contextualizing with narrating proper, possibly because his ideology provides a grand dramatic structure. His story of slavery in America, ${ }^{6}$ like E.P. Thompson's story of the English working class, ${ }^{7}$ succeeds because of its exquisite attention to detail and nuance, to the thing-to-be-xplained. However, it is by no means self-evident that, as Genovese insists, power struggle (either of the Freudian or marxist variety) is at the center of history, wherever that may be. That history is "primarily the story of who rides whom and how" is an assertion that would be outrageous were it not so silly.

In reaction to a historiography that has placed too much emphasis on political and social consensus, especially in the Anglo-American world, historians should insist upon the inevitability of conflict in human affairs. They should insist that certain persistent forms of conflict, of which class conflict is one of the most important, be given particular attention. They are doing both. But there is little danger they will agree to abandon the study of people who happen not to be sub- or super-ordinating, who may instead be cooperating, or sublimating, or worshipping, or doing any of the other compelling things that people do. In insisting upon this point, Shorter is perfectly correct, as are countless other historians who do not share his desire to develop "scientific" methods in history. Indeed, at the very moment when both marxist and social scientific agendas seem to have penetrated, even conquered, the centers of academic respectability, their advocates sound more urgent (I will not say desperate) calls for disciplinary diagnosis and therapy. The new harlots of cultural anthropology, "thick description," and semiotics threaten daily to shift the focus, to alter the terms of discourse. ${ }^{8}$ Moreover, "traditional" historians are theorizing and perfecting methods, partly in response to the new social historians' challenge and partly because they do that sort of thing from time to time. David Hollinger's recent essay, "Historians and the Discourse of In- 
tellectuals" demonstrates the way in which one intellectual historian has responded thoughtfully to the need to enrich the vertical, contextual dimension of the history of ideas. ${ }^{9}$

What is wrong with social history? Well, what is wrong with history? Historians of all kinds regularly feel the need to revitalize their narrative, to recontextualize, find new voices, and borrow new techniques of "vertical" analysis. Intellectual and political historians have in the past been guilty of excessive "horizontalization," of Great Man explanations, and of faulty inferences from single persons and doctrines to masses. Social historians seem especially susceptible to getting bogged down in context analysis, confusing contexts with causes, and getting carried away with Big Agendas for reinterpreting vast stretches of history and for establishing the discipline as a predictive science. All can benefit from a reconsideration of the uses of narrative.

University of Michigan

\section{NOTES}

1. This paper should be taken in the same spirit in which it was given. It was meant to be a serious - though not too serious - position paper, designed to stake out a defensible terrain and to mark out a visible target for other discussants. I have made a few changes, but the text remains substantially as given. In a different context almost every sentence would call for qualification and amplification. But I would not wish to alter the thrust of the argument: history is essentially a collection of stories and the new social history is but a recent movement to refurbish the contexts and replenish the supply of stories available to historians.

2. The sense in which that sequence should be understood as causal is best clarified by Michael Scriven, "Causes, Connections and Conditions in History," in William H. Dray, ed., Philosophical Analysis and History (Harper \& Row, 1966); see also his "Truisms as the Grounds for Historical Explanations," in Patrick Gardiner, ed., Theories of History (The Free Press, 1959).

3. Gene Wise, American Historical Explanations: A Strategy for Grounded Inquiry (The Dorsey Press, 1973).

4. Illustrations, extended quotations, and including documents in appendices and in the text already provide an element of multi-perspectival narrative in history.

5. Raymond Williams to the contrary notwithstanding, this confusion is common to marxists and devotees of modernization theory. See Williams' "Base and Superstructure in Marxist Cultural Theory," New Left Review (Nov-Dec, 1973), 3-16, or his Marxism and Literature (Oxford University Press, 1977), 75-82. For a manifesto directed against all manner of cultural materialism and naturalism, see Marshall Sahlins, Culture and Practical Reason (University of Chicago Press, 1976).

6. Eugene D. Genovese, Roll, Jordan, Roll: The World the Slaves Made (Pantheon Books, 1974).

7. E.P. Thompson, The Making of the English Working Class (Pantheon Books, 1963).

8. For an interesting discussion of these trends in relation to labor history in America, see Robert P. Baker, "Labor History, Social Science, and the Concept of the Working Class," Labor History (Winter 1973), 98-105.

9. David A. Hollinger, "Historians and the Discourse of Intellectuals," in John Higham and Paul K. Conkin, eds., New Directions in American Intellectual History (Johns Hopkins University Press, 1979). 